\title{
Differential responses of esterase isoenzyme of peanut to salinity and drought as influenced by salicylic acid
}

\author{
Dia M. Soltan and Jehan M. Salem \\ Central Laboratory of Genetic Engineering, Faculty of Science, Sohag University, 82524 Sohag, Egypt.
}

Rec. 28 Dec, 2016 Accept. 27 Feb, 2017

\begin{abstract}
The effect of salinity, drought and salicylic acid on growth and esterase expression of peanut plants were studied.Seeds of peanut were able to germinate even under relatively high concentration of $\mathrm{NaCl}(157.5 \mathrm{mM})$ or PEG $(25 \%)$. In general, seedling growth was less tolerant to salt stress than vegetative growth stage of peanut plants grown in hydroponic culture containing $\mathrm{NaCl}$, vice versa was detected when PEG was used.While the application of $0.1 \mathrm{mM}$ salicylic acid (SA), inhibit peanut seed germination, it improved seedling and vegetative growth parameters under moderate concentration of $\mathrm{NaCl}(105 \mathrm{mM})$. Seedling and vegetative growth parameters were significantly reduced by increase the concentrations of PEG. Application of SA improved growth parameters of peanut plants subjected to $10 \%$ PEG.In hydroponic culture, peanut was more sensitive to PEG than $\mathrm{NaCl}$ where plants wilted in three days under relatively high PEG concentrations. Root of peanut seedlings increased the esterase expression under the influence of moderate salinity $(105 \mathrm{mM})$ and drought $(10 \%$ PEG) stresses through increase the number and staining intensity of isoenzyme forms.Increase the number of isoenzyme forms and/or staining intensity as an indicator of increased activity of the enzyme was detected when peanut plants were hydroponically grown in solution with relatively high $\mathrm{NaCl}$ or PEG.Application of SA increased the number and/or the staining intensity of isoenzyme forms during seedling or vegetative growth in hydroponic culture containing relatively high concentration of $\mathrm{NaCl}$ or PEG.
\end{abstract}

Key words: $\mathrm{NaCl}$, polyethylene glycol, esterase isoenzyme, salicylic acid, seed germination, Arachis hypogaea.

\section{Introduction}

Among biotic and abiotic factors, salinity and drought affect negatively on the productivity of agricultural systems which hinders future governmental plans to achieve enough food. Since man cannot stop desertification and soil salinization, they must increase the ability of plants to survive and maintain their economic growth under drought and saline conditions (Ashraf, 2009; Qadir et al. 2014).

Polyethylene glycol (PEG 6000) is an inert osmotic agent which cannot penetrate the apoplast, so it results in water withdrawn from the cell and cell wall. Consequently, PEG was used as an available and cheap factor to mimic drought under field conditions (Verslues et al., 2006). Availability of low water is the main aspect under the influence of both drought and salinity. In addition to osmotic stress, plants suffer from ion toxicity of both $\mathrm{Na}^{+}$and $\mathrm{Cl}^{-}$ under salinity stress. To ensure plant survival, plants develop specific mechanisms to control the negative effects of osmoticum and ion toxicity (Mahajan and Tuteja, 2005), the key action of these mechanisms is modulation of gene expression.

\footnotetext{
* Corresponding author:

Dr. Jehan M. Salem

$凶$ hashsalem@yahoo.com
} 
Well seed germination and seedling growth should be established as guarantee for continuous vegetative growth leading to commercial yield (Karagić et al., 2010) but it depended on the suitability of the environmental conditions. On the other hand, un-favorite conditions including salinity or water stress retarded these stages (Kalefetoglu Macar et al., 2009). Oil producing plants, such as peanut, expressed a valuable degree of salinity tolerance via accumulation of lipids as osmoregulation (Younis et al., 1987; AbdelRahman and Hassanein, 1988; Hassanein, 1999). During seed germination, lipid hydrolysis was increased due to the increase ester-hydrolyzing enzymes resulting in free fatty acids from triglycerides for $\beta$-oxidation in the glycoxysome (Devlin and Witham, 1986; Younis et al., 1987). Esterases are proteins which hydrolyze ester bonds and are present in several isoenzyme forms. Esterases have hydrolytic action on broad range of substrates and they could be used as a molecular marker for somatic embryogenesis and organogenesis (Hassanein et al., 1999). Under the influence of biotic and abiotic stresses, variation in esterase expression was registered in peanut (Hassanein, 1999) in barley (Tamás et al., 2005) and tomato (Hassanein, 2004).

Previous studies indicated that salicylic acid (SA) was used as a hormone-like substance due to its important role in photosynthesis, stomatal function, transpiration, antioxidation and inhibition of $\mathrm{Na}^{+}$and $\mathrm{Cl}^{-}$accumulations (Gunes et al., 2007; Arfan et al., 2007; Xu et al., 2008). Consequently, it was used to alleviate environmental stress such as salinity and drought (Shakirova et al., 2003; Singh and Usha, 2003). On the other side, exogenous application of SA in rooting medium of maize inhibited plant growth (Nemeth et al. (2002). While induction of abiotic stress tolerance was not detected by SA in plants, application of SA by pre-soaking of seeds, incorporation in hydroponic culture, in water of irrigation or foliar application improved growth of plants under abiotic stresses (El-Tayeb, 2005; Szepesi et al., 2009).
Plants change protein expression during development and/or stress condition. It is regulated before or after transcription (Scandalios, 1974). Variation in gene expression can be detected by studying the expression of isoenzymes and/or SDS PAGEs. In this concern, appearance or disappearance of isoenzyme gives an indication about how gene expression is influenced by specific agent. In addition, change in staining intensity of one or more bands indicates to change in the enzyme activity (Khavkin and Zabordina, 1994; Hassanein et al., 1999). Also, this indicates that genes involved in expression of these isoenzyme forms are differentially expressed under the influence of studied biotic or abiotic condition (Chawla, 1991; Hassanein et al., 1999; El-Tayeb and Hassanein,2000). Comparative studies on esterase isoenzyme expression under different abiotic stresses in oil producing plants were limited. Then, the objective of this study was to clarify the differential responses of esterase isoenzyme expression of peanut to salinity and drought stresses at different developmental growth stages in the absence or presence of SA. In addition, this work investigated which stage of peanut growth was more sensitive for salt or drought stress: seed germination, seedling or vegetative growth stage.

\section{Materials and methods \\ Seed germination and seedling growth as influenced by different concentrations of NaCl or PEG:}

Peanut seeds (Arachis hypogaeacv; cultivar Shandaweel 1) were obtained from Sohag Agricultural Research Center, Sohag, Egypt. Uniform-healthy seeds were germinated in plastic pots $(11 \mathrm{~cm}$ width $\mathrm{x} 9 \mathrm{~cm}$ height $)$ containing sawdust. Each pot was irrigated with $200 \mathrm{ml}$ of $1 / 4$ strength of Hoagland solution (Hoagland and Arnon, 1950) containing different concentrations of $\mathrm{NaCl}$ $(0.0,45,105$ or $157.5 \mathrm{mM})$ or polyethylene glycol $6000(0,5,10,15,20,25$ or $30 \%)$ with or without $0.1 \mathrm{mM}$ salicylic acid (SA). Seeds were germinated under controlled condition $\left(26 \pm 2{ }^{\circ} \mathrm{C}\right.$ at $16 / 8 \mathrm{~h}$ photoperiod of $100 \mu \mathrm{mol}$ $\mathrm{m}^{-2} \mathrm{~s}^{-1}$ irradiance and $70 \%$ relative humidity) for 15 days. Three replicates with five seeds 
per each were used for each treatment. Percentage of seed germination, root and shoot lengths, and leaf number/shoot were estimated. Also, fresh and dry masses, and water content of root, stem and leaves were determined. Esterase expression under the influence of different treatments of salinity or drought was analyzed in seedlings roots and shoots.

\section{Hydroponic plant growth as influenced by different concentrations of $\mathrm{NaCl}$ or PEG:}

Peanut plants obtained from seeds germinated in sawdust irrigated with tap water for ten days were transferred to grow in hydroponic cultures to investigate the effect of different concentrations of $\mathrm{NaCl}$ or PEG with or without SA on plant growth. The hydroponic cultures were established by placing plants in conical flasks $(250 \mathrm{ml})$ containing $200 \mathrm{ml}$ of Hoagland solution (1/2 strength) and supplemented with different concentrations of $\mathrm{NaCl}(0,45,105$ or 157.5 $\mathrm{mM})$ or PEG $(0,5,10,15,20,25$ or $30 \%)$ with or without $0.1 \mathrm{mM} \mathrm{SA}$. Three replicates with three plants/each were used for each treatment. Conical flasks were wrapped with aluminum foil to prevent the exposure of roots to light. Cultures were incubated under controlled conditions for 15 or three days for salinity or drought, respectively. Cultures were daily aerated for 5 min by using aeration pump. Growth parameters were estimated. Esterase expression under the influence of different treatments of salinity and/or drought was studied in roots, stems and leaves.

\section{Esterase isoenzyme analysis}

One gram of plants grown under the influence of different treatments was grounded on ice in $2 \mathrm{ml}$ homogenization buffer $(0.1 \mu \mathrm{M}$ Tris-HCl, $\mathrm{pH} 7.0$ and $2 \mathrm{mM}$ cystein). The obtained homogenates were subjected for centrifugation at $15000 \mathrm{rpm}$ for $15 \mathrm{~min}$ using cooling centrifuge at $4{ }^{\circ} \mathrm{C}$. Supernatants were collected using micropipette and transferred for immediate electrophoresis using $7.5 \%$ polyacrylamide slab gels. In each well, $100 \mu 1$ of supernatant of each sample were loaded. Electrophoresis was carried out for $6 \mathrm{~h}$ at 10 ${ }^{\circ} \mathrm{C}$ in run buffer $(0.025 \mathrm{M}$ Tris-base $+0.192 \mathrm{M}$ glycine ( $\mathrm{pH}$ 8.9) with $2 \mathrm{~mA}$ per sample.
Esterases were detected following staining method described by Brewer (1970).

\section{Statistical analysis}

Data were presented as means \pm standard deviation (SD) as described by Snedecor and Cochran (1980). Analysis of variance (ANOVA) was carried out using the software of SPSS 16, the significance level was measured, $P \leq 0.05$ was considered as significant.

\section{Result and discussion}

Salinity and drought are two of the major environmental abiotic stresses in Egypt and many other countries, consequently, they were the subject of this study. Seed germination and seedling growth of peanut were decreased under the influence of salt stress (Table 1). The ability of peanut to geminate was 93.3 and $80 \%$ under relatively moderate and high salt stress, respectively. This ability of high seed germination of peanut under slat stress can be used to cultivate peanut commercially in saline soil.Seed germination is considered the most important developmental phase in the plant life and it is affected by salinity (Misra and Dwivedi, 2004). On the other side, most of seedling growth parameters such as root and stem lengths, leaves number, and root, stem and leaves fresh masses were significantly decreased under salt stress. Under the influence of highest $\mathrm{NaCl}$ concentration, the values of root and shoot fresh masses were reduced by 77.64 and $56 \%$, respectively. It indicated that salt stress adversely affected root growth more than shoot growth as was reported by Van-De-Vanter (2001). Reduction in root and shoot growth was considered the most important indicator for the response of plants to environmental stresses (Jamil and Rha, 2004).

Under the influence of salt stress, seed germination of peanut was decreased by the application of SA as was reported by Jadhav and Bhamburdekar (2011). On the other side, the enhancing effect of SA on seed germination under slat stress was reported in other plants (McCue et al., 2000; Shakirova et $a l ., 2003)$. Salicylic acid improved the growth parameters of roots of unstressed and stressed peanut seedlings (Table 1), it may be due to 
increase the water content of the plant organs. Under moderate $\mathrm{NaCl}$ condition, SA improved the determined seedling growth parameters. Under the effect of the highest $\mathrm{NaCl}$ concentration, SA improved slightly the water content of roots and it was associated with increase root growth (length and fresh weight). The increase in fresh and dry matter of salt stressed plants due to the application of SA was related to induction of antioxidants and salt tolerant in plants (Gunes et al., 2005).

\begin{tabular}{|c|c|c|c|c|c|c|c|c|c|c|}
\hline $\begin{array}{c}\mathrm{NaCl} \\
\mathrm{Coc} . \\
(\mathrm{mM}) \\
\end{array}$ & $\begin{array}{c}\text { Germination } \\
\text { percentage } \\
(\%)\end{array}$ & $\begin{array}{l}\text { Root } \\
\text { length } \\
(\mathbf{c m})\end{array}$ & $\begin{array}{l}\text { Stem } \\
\text { length } \\
(\mathrm{cm})\end{array}$ & $\begin{array}{c}\text { No. of } \\
\text { leaves/shoot }\end{array}$ & $\begin{array}{l}\text { Root } \\
\text { F.W } \\
\text { (g) }\end{array}$ & $\begin{array}{l}\text { Stem } \\
\text { F.W. } \\
\text { (g) }\end{array}$ & $\begin{array}{l}\text { Leaves } \\
\text { F.W. } \\
\text { (g) }\end{array}$ & $\begin{array}{l}\text { Root } \\
\text { W.C. } \\
(\%)\end{array}$ & $\begin{array}{l}\text { Stem } \\
\text { W.C. } \\
(\%)\end{array}$ & $\begin{array}{l}\text { Leaf } \\
\text { W.C. } \\
(\%)\end{array}$ \\
\hline $\begin{array}{c}\mathbf{0 . 0} \\
\text { (Control) }\end{array}$ & 100 & $9.1 \pm 1.35$ & $8 \pm 1.37$ & $7.00 \pm 0.57$ & $1.61 \pm 0.00$ & $0.75 \pm 0.03$ & $1.38 \pm 0.19$ & $84.95 \pm 0.86$ & $83.36 \pm 0.29$ & $82.77 \pm 0.58$ \\
\hline 45 & 100 & $5.7 * \pm 0.17$ & $5.77 \pm 0.25$ & $6.00 * \pm 0.00$ & $1.12 \pm 0.10$ & $0.57 \pm 0.06$ & $0.69 * \pm .17$ & $82.72 * \pm 0.97$ & $82.51 \pm 1.93$ & $81.84 \pm 1.79$ \\
\hline 105 & 93.33 & $5.00 * \pm 1.00$ & $3.37 * \pm 0.40$ & $6.00 * \pm 0.00$ & $0.58^{*} \pm 0.14$ & $0.35 * \pm 0.02$ & $0.35 * \pm 0.04$ & $83.88 \pm 0.84$ & $81.70 \pm 1.54$ & $80.74 \pm 0.29$ \\
\hline 157.5 & 80 & $3.33^{*} \pm 0.75$ & $3.00 * \pm 0.20$ & $4.00 * \pm 1.00$ & $0.36^{*} \pm 0.10$ & $0.33^{*} \pm 0.05$ & $0.24 * \pm 0.04$ & $81.35^{*} \pm 0.36$ & $83.43 \pm 0.35$ & $80.51 \pm 1.43$ \\
\hline $0.0+\mathrm{SA}$ & 100 & $9.7 \pm 1.04$ & $8.70 \pm 1.7$ & $7.00 \pm 0.00$ & $1.85 \pm 0.16$ & $0.79 \pm 0.10$ & $1.29 \pm 0.22$ & $86 \pm 0.38$ & $85.31 \pm 0.75$ & $84.43 \pm 0.55$ \\
\hline $45+$ SA & 100 & $7 \pm 1.04$ & $5.5 \pm 1.05$ & $6^{*} \pm 0.00$ & $1.51 \pm 0.31$ & $0.73 \pm 0.06$ & $0.86^{*} \pm 0.27$ & $81.05 * \pm 0.26$ & $82.41 \pm 1.51$ & $81.66 \pm 1.32$ \\
\hline $105+\mathrm{SA}$ & 80 & $6.6 \pm 1.56$ & $4.13^{*} \pm 0.23$ & $6^{*} \pm 0.00$ & $0.89^{*} \pm 0.28$ & $0.43^{*} \pm 0.08$ & $0.53^{*} \pm 0.12$ & $83.18 \pm 0.83$ & $81.92 \pm 1.55$ & $80.86 \pm 1.13$ \\
\hline $157.5+$ SA & 66.67 & $4.33^{*} \pm 0.76$ & $2.27 * \pm 0.40$ & $4 * \pm 0.00$ & $0.51 * \pm 0.03$ & $0.30 * \pm 0.06$ & $0.24 * \pm 0.08$ & $82.92 * \pm 0.19$ & $81.16 \pm 1.69$ & $78.54 * \pm 0.44$ \\
\hline
\end{tabular}

Table 1. Germination and seedling growth of peanut seeds sown for 15 days in sawdust saturated with $200 \mathrm{ml}$ Hoagland solution (1/4 strength) supplemented with different concentrations of $\mathrm{NaCl}$ without or with $0.1 \mathrm{mM} \mathrm{SA}$ at 26 $\pm 2{ }^{\circ} \mathrm{C}$ and $16 / 8 \mathrm{~h}$ photoperiod. Values are mean $\pm \mathrm{SD}$. $*$ Sign to significant difference between the control and other treatments at $P \leq 0.5$.

After two weeks in hydroponic culture, peanut plants showed reduction of the estimated growth parameters (Table 2). The sensitivity of peanut plant to salt in hydroponic culture was higher than that in the soil, where low $\mathrm{NaCl}$ impaired growth parameters when peanut plants were grown in nutrient solution containing relatively low $\mathrm{NaCl}$ concentration $(45 \mathrm{mM})$, but vice versa in soil containing the same concentration of $\mathrm{NaCl}$ (Hassanein 1999). Under the influence of moderate or high $\mathrm{NaCl}$ concentrations, although the root and stem growth parameters were significantly reduced at the seedling stage (Table 1), they showed non-significant reduction when vegetative growth of plants was carried out in hydroponic cultures (Table 2). In general, vegetative growth stage of peanut was more tolerant to salinity than seedling growth stage. In addition, peanut roots in the vegetative growth stage were less adversely affected by high salt concentrations than stems. Many researches illustrated that the inhibition in plant growth under salt stress can be attributed to disturbance in $\mathrm{Na}^{+}$and $\mathrm{Cl}^{-}$ions homeostasis, closure of stomata, and ROS raised production in chloroplasts (Meneguzzo et al., 1999; Steduto et al., 2000).
In hydroponic cultures, salicylic acid improved the growth of unstressed peanut plants and alleviated the negative effect of $\mathrm{NaCl}$ on vegetative growth and water content of different plant organs when plants were subjected to moderate concentration of $\mathrm{NaCl}$ (Table 2). Salicylic acid improved the adversely effect of salinity on fresh and dry masses in many plants (Shakirova et al., 2003; El-Tayeb, 2005; Baninasab and Baghbanha, 2013).

Polyethylene glycol had a negative effect on seeds germination of peanut especially under relatively high concentrations (Table 3 ). All seedling growth parameters were significantly reduced by increasing PEG concentration (Table 3). Germination percentage and seedling growth of plants were inhibited by sever stresses due to limitation in water uptake, reduction in enzymes activity, photosynthesis disorder and disturbance in seedling growth (Takel,2000; Kabiri et al., 2012). Relatively low PEG concentration (5\%) increased root length compared with control. Data in Table 3 indicated that shoot growth was adversely influenced more than root growth under drought stress as was reported previously (Liu et al., 2011). 


\begin{tabular}{|c|c|c|c|c|c|c|c|c|c|}
\hline $\begin{array}{c}\mathrm{NaCl} \\
\mathrm{Coc} . \\
\text { (mM) }\end{array}$ & $\begin{array}{c}\text { Root } \\
\text { Length } \\
\text { (cm) }\end{array}$ & $\begin{array}{l}\text { Stem } \\
\text { Length } \\
\text { (cm) }\end{array}$ & $\begin{array}{c}\text { No. of leaves/ } \\
\text { shoot }\end{array}$ & $\begin{array}{l}\text { Root } \\
\text { F.W } \\
\text { (g) }\end{array}$ & $\begin{array}{l}\text { Stem } \\
\text { F.W. } \\
\text { (g) }\end{array}$ & $\begin{array}{l}\text { Leaves } \\
\text { F.W. } \\
\text { (g) }\end{array}$ & $\begin{array}{l}\text { Root } \\
\text { W.C. } \\
(\%)\end{array}$ & $\begin{array}{l}\text { Stem } \\
\text { W.C. } \\
(\%)\end{array}$ & $\begin{array}{c}\text { Leaves } \\
\text { W.C. } \\
(\%)\end{array}$ \\
\hline $\begin{array}{c}0.0 \\
\text { (Control) }\end{array}$ & $12.23 \pm 1.37$ & $18 \pm 1$ & $11 \pm 0.00$ & $1.72 \pm 0.34$ & $1.19 \pm 0.11$ & $2.33 \pm 0.32$ & $91.61 \pm 0.17$ & $84.78 \pm 1.28$ & $86.28 \pm 0.66$ \\
\hline 105 & $10.57 \pm 0.32$ & $11.06^{*} \pm 0.50$ & $9.00 * \pm 0.00$ & $1.37 \pm 0.11$ & $0.86 \pm 0.13$ & $1.23^{*} \pm 0.22$ & $90.94 \pm 0.86$ & $79.64 \pm 0.66$ & $78.80 * \pm 1.01$ \\
\hline 157.5 & $10.23 \pm 0.89$ & $9.93 * \pm 1.79$ & $8.66 * \pm 0.57$ & $1.25 \pm 0.259$ & $0.84 \pm 0.08$ & $1.10 * \pm 0.14$ & $91.20 \pm 0.41$ & $83.93 \pm 1.85$ & $69.09 * \pm 1.56$ \\
\hline $45+S A$ & $14.03 \pm 4.37$ & $13.3^{*} \pm 0.3$ & $10^{*} \pm 0.00$ & $1.43 \pm 0.09$ & $1.10 \pm 0.11$ & $2.48 \pm 0.46$ & $91.95 \pm 0.67$ & $85.19 \pm 1.19$ & $84.89 \pm 1.07$ \\
\hline $105+\mathrm{SA}$ & $11.27 \pm 0.14$ & $11.87^{*} \pm 2.68$ & $8.33^{*} \pm 0.57$ & $1.41 \pm 0.14$ & $1.004 \pm 0.25$ & $1.45^{*} \pm 0.25$ & $91.55 \pm 0.56$ & $84.52 \pm 2.27$ & $83.46 \pm 0.69$ \\
\hline $157.5+$ SA & $10.73 \pm .64$ & $11.47 * \pm 0.30$ & $7 * \pm 0.00$ & $1.03 * \pm 0.06$ & $1.05 \pm 0.08$ & $1.02 * \pm 0.10$ & $89.21 * \pm 0.67$ & $81.09 \pm 5.37$ & $75.26 * \pm 6.03$ \\
\hline
\end{tabular}

Table 2. Growth parameters of peanut plants were hydroponically cultured for 15 days in Hoagland solution (1/2 strength) supplemented with different concentration of $\mathrm{NaCl}$ in the absence or presence of $0.1 \mathrm{mM} \mathrm{SA}$ at $26 \pm 2{ }^{\circ} \mathrm{C}$ and $16 / 8 \mathrm{~h}$ photoperiod. Values are mean $\pm \mathrm{SD}$. * Sign to significant difference between the control and other treatments at $\mathrm{P} \leq 0.5$

Inclusion of SA with PEG slightly improved seedling growth of peanut grown at $10 \%$ PEG. Also, the positive effect of SA on seedling growth appeared in untreated control plants. Under the effect $15 \%$ PEG, SA only increased the stem growth and water contents of different plant organs. The stimulating effect of SA on germination and dry weight of water stressed plants may be due to increase antioxidants that protect the plant from oxidative damage (Baalbaki et al., 1999; Singh and Usha, 2003). Nemeth et al. (2002) found that supplementing root medium with SA inhibited the growth of maize under drought stress.

\begin{tabular}{|c|c|c|c|c|c|c|c|c|c|c|}
\hline $\begin{array}{l}\text { PEG } \\
\text { Conc. } \\
(\%)\end{array}$ & $\begin{array}{c}\text { Germination } \\
\text { percentage } \\
(\%)\end{array}$ & $\begin{array}{l}\text { Root } \\
\text { length } \\
(\mathrm{cm})\end{array}$ & $\begin{array}{l}\text { Stem } \\
\text { Length } \\
\text { (cm) }\end{array}$ & $\begin{array}{c}\begin{array}{c}\text { No. of } \\
\text { leaves/shoot }\end{array} \\
\end{array}$ & $\begin{array}{l}\text { Root } \\
\text { F.W } \\
\text { (g) }\end{array}$ & $\begin{array}{l}\text { Stem } \\
\text { F.W. } \\
(\mathrm{g})\end{array}$ & $\begin{array}{l}\text { Leaves } \\
\text { F.W. } \\
\text { (g) }\end{array}$ & $\begin{array}{l}\text { Root } \\
\text { W.C. } \\
(\%)\end{array}$ & $\begin{array}{l}\text { Stem } \\
\text { W.C. } \\
(\%)\end{array}$ & $\begin{array}{l}\text { Leaves } \\
\text { W.C. } \\
(\%)\end{array}$ \\
\hline $\begin{array}{c}0.0 \\
\text { (control) }\end{array}$ & 100 & $9.1 \pm 1.35$ & $8 \pm 1.37$ & $7.00 \pm 0.00$ & $1.03 \pm 0.11$ & $0.75 \pm 0.03$ & $1.38 \pm 0.19$ & $84.95 \pm 0.86$ & $83.36 \pm 0.29$ & $82.77 \pm 0.58$ \\
\hline 5 & 100 & $9.50 \pm 1.3$ & $7.27 \pm 0.46$ & $6.00 * \pm 0.00$ & $0.90 \pm 0.14$ & $0.61 \pm 0.03$ & $0.88 * \pm 0.21$ & $80.26 \pm 0.29$ & $81.46 \pm 1.96$ & $81.82 \pm 1.32$ \\
\hline 10 & 100 & $5.10^{*} \pm 0.70$ & $2.40^{*} \pm 0.10$ & $5.33 * \pm 0.57$ & $0.34 * \pm 0.06$ & $0.19^{*} \pm 0.02$ & $0.31 * \pm 0.09$ & $75.72 * \pm 1.33$ & $75.72 \pm 1.16$ & $73.72 * \pm 2.16$ \\
\hline 15 & 100 & $4.67 * \pm 0.06$ & $0.67 * \pm 0.15$ & $2.00 * \pm 0.00$ & $0.25 * \pm 0.04$ & $0.04 * \pm 0.01$ & $0.04 * \pm 0.008$ & $72.25^{*} \pm 6.89$ & $64.07 * \pm 3.52$ & $72.83^{*} \pm 0.27$ \\
\hline 20 & 66.67 & $4.5^{*} \pm 0.26$ & $0.63^{*} \pm 0.05$ & $2.00 * \pm 0.00$ & $0.05 * \pm 0.007$ & $0.03 * \pm 0.009$ & 0 & $69.27^{*} \pm 1.003$ & $56.85 * \pm 0.81$ & 0 \\
\hline 25 & 66.67 & $0.50 * \pm 0.10$ & 0 & 0 & $0.03 * \pm 0.01$ & 0 & 0 & $67.95 * \pm 2.13$ & 0 & 0 \\
\hline $0.0+\mathrm{SA}$ & 100 & $9.7 \pm 1.04$ & $8.70 \pm 1.7$ & $7.00 \pm 0.00$ & $1.85 * \pm 0.16$ & $0.79 \pm 0.10$ & $1.29 \pm 0.22$ & $86.31 \pm 0.38$ & $85.31 \pm 0.75$ & $84.43 \pm 0.55$ \\
\hline $5+$ SA & 100 & $7.33 \pm 0.15$ & $4.17 * \pm 0.05$ & $6.00 * \pm 0.00$ & $0.49 * \pm 0.13$ & $0.31 * \pm 0.09$ & $0.54 * \pm 0.17$ & $80.58 \pm 0.8$ & $78.96 \pm 1.01$ & $77.86 \pm 1.20$ \\
\hline $10+$ SA & 100 & $5.53 * \pm 0.28$ & $3.13^{*} \pm 0.75$ & $5.33 * \pm 0.57$ & $0.64 * \pm 0.06$ & $0.36 * \pm 0.06$ & $0.51 * \pm 0.08$ & $77.44 \pm 2.83$ & $73.95^{*} \pm 3.14$ & $73.63 * \pm 3.09$ \\
\hline $15+\mathrm{SA}$ & 100 & $3.53 * \pm 0.41$ & $0.70^{*} \pm 0.10$ & $2.00 * \pm 0.00$ & $0.08 * \pm 0.02$ & $0.05^{*} \pm 0.01$ & $0.035 * \pm 0.01$ & $75.37 * \pm 1.45$ & $65.3^{*} \pm 7.97$ & $74.77 \pm 9.56$ \\
\hline $20+$ SA & 66.67 & $1.23 * \pm 0.25$ & $0.53^{*} \pm 0.05$ & $2.00 * \pm 0.00$ & $0.06 * \pm 0.007$ & $0.04 * \pm 0.01$ & 0 & $70.09 * \pm 4.37$ & $58.31 * \pm 4.86$ & 0 \\
\hline $25+$ SA & 66.67 & $0.47 * \pm 0.21$ & 0 & 0 & $0.04 * \pm 0.01$ & 0 & 0 & $45.68 * \pm 3.84$ & 0 & 0 \\
\hline
\end{tabular}

Table 3. Germination and seedling growth of peanut seeds sown for 15 days in sawdust saturated with $200 \mathrm{ml}$ Hoagland solution (1/4 strength) supplemented with different concentrations of PEG without or with $0.1 \mathrm{mM} \mathrm{SA}$ at 26 $\pm 2{ }^{\circ} \mathrm{C}$ and $16 / 8 \mathrm{~h}$ photoperiod. Values are mean $\pm \mathrm{SD}$. $*$ Sign to significant difference between the control and other treatments at $P \leq 0.5$.

Peanut vegetative growth stage was very sensitive to $\mathrm{PEG}_{6000}$, where, all the cultured plants started to wilt within three days, especially under the influence of relatively high concentration of PEG (25\%). Root, stem and leaves fresh masses as well as root and leaves water contents of peanut plants were significantly reduced under the effect of PEG concentrations more than $5 \%$ in the absence or presence of SA (Table 4). Peanut was more sensitive to PEG than $\mathrm{NaCl}$ during seedling and vegetative growth.These results are in accordance with other reports (Radic and Pevalek-Kozlina 2010; Petrovic et al., 2016).It obvious that responses of peanut to saline and drought stresses differed according to developmental stage and the type of stress. 


\begin{tabular}{|c|c|c|c|c|c|c|c|c|c|}
\hline $\begin{array}{c}\text { PEG } \\
\text { Conc. } \\
(\%)\end{array}$ & $\begin{array}{c}\text { F.W.I } \\
\text { Root } \\
\text { (g) }\end{array}$ & $\begin{array}{l}\text { D.W. I } \\
\text { Root } \\
\text { (g) }\end{array}$ & $\begin{array}{l}\text { Root } \\
\text { W.C. } \\
(\%)\end{array}$ & $\begin{array}{l}\text { F.W.I } \\
\text { Stem } \\
\text { (g) }\end{array}$ & $\begin{array}{l}\text { D.W.I } \\
\text { Stem } \\
\text { (g) }\end{array}$ & $\begin{array}{l}\text { Stem } \\
\text { W.C. } \\
(\%)\end{array}$ & $\begin{array}{c}\text { F.W.I } \\
\text { Leaves } \\
\text { (g) }\end{array}$ & $\begin{array}{l}\text { D.W. I } \\
\text { Leaves } \\
\text { (g) }\end{array}$ & $\begin{array}{c}\text { Leaves } \\
\text { W.C. } \\
(\%)\end{array}$ \\
\hline $\begin{array}{c}\mathbf{0 . 0} \\
\text { (control) }\end{array}$ & $2.24 \pm 0.25$ & $0.17 \pm 0.03$ & $93.23 \pm 0.20$ & $0.98 \pm 0.13$ & $0.15 \pm 0.02$ & $84.60 \pm 1.16$ & $1.15 \pm 0.17$ & $0.18 \pm 0.02$ & $84.63 \pm 0.59$ \\
\hline 5 & $1.22 * \pm 0.06$ & $0.14 \pm 0.008$ & $88.72 * \pm 0.1$ & $0.68 \pm 0.10$ & $0.12 \pm 0.03$ & $82.69 \pm 2.28$ & $0.86 \pm 0.18$ & $0.20 \pm 0.02$ & $75.94 \pm 2.89$ \\
\hline 10 & $1.13 * \pm 0.06$ & $0.14 \pm 0.01$ & $87.49 * \pm 1.33$ & $0.63^{*} \pm 0.03$ & $0.12 \pm 0.01$ & $79.66 \pm 3.49$ & $0.76^{*} \pm 0.06$ & $0.19 \pm 0.02$ & $73.83^{*} \pm 0.83$ \\
\hline 15 & $1.05 * \pm 0.10$ & $0.16 \pm 0.02$ & $84.85^{*} \pm 0.89$ & $0.55^{*} \pm 0.04$ & $0.11 \pm 0.01$ & $79.15 \pm 1.57$ & $0.48 * \pm 0.01$ & $0.19 \pm 0.003$ & $59.14 * \pm 0.43$ \\
\hline 20 & $1.03 * \pm 0.28$ & $0.16 \pm 0.04$ & $83.65^{*} \pm 0.50$ & $0.55^{*} \pm 0.08$ & $0.12 \pm 0.01$ & $76.91 \pm 1.51$ & $0.38^{*} \pm 0.09$ & $0.18 \pm 0.01$ & $52.05^{*} \pm 7.13$ \\
\hline 25 & $0.94 * \pm 0.17$ & $0.18 \pm 0.05$ & $81.4^{*} \pm 2.49$ & $0.44^{*} \pm 0.05$ & $0.12 \pm 0.02$ & $71.64 * \pm 9.46$ & $0.26^{*} \pm 0.007$ & $0.16 \pm 0.009$ & $38.04 * \pm 1.86$ \\
\hline $0.0+\mathrm{SA}$ & $1.45 * \pm 0.19$ & $0.15 \pm 0.01$ & $89.82 \pm 0.35$ & $1.09 \pm 0.19$ & $0.14 \pm 0.03$ & $86.98 \pm 1.11$ & $2.11 * \pm 0.12$ & $0.29 * \pm 0.02$ & $86.08 \pm 0.40$ \\
\hline $5+\mathrm{SA}$ & $0.98 * \pm 0.03$ & $0.13 \pm 0.004$ & $86.69 * \pm 0.24$ & $0.87 \pm 0.07$ & $0.14 \pm 0.02$ & $83.36 \pm 1.31$ & $1.35 \pm 0.22$ & $0.27 \pm 0.01$ & $79.41 \pm 3.21$ \\
\hline $10+\mathrm{SA}$ & $0.99 * \pm 0.28$ & $0.13 \pm 0.03$ & $86.48^{*} \pm 0.48$ & $0.84 \pm 0.13$ & $0.12 \pm 0.01$ & $85.69 \pm 1.72$ & $0.81 \pm 0.11$ & $0.20 \pm 0.005$ & $73.93 * \pm 4.88$ \\
\hline $15+\mathrm{SA}$ & $0.63 * \pm 0.09$ & $0.10 \pm 0.02$ & $85.03^{*} \pm 1.71$ & $0.67^{*} \pm 0.03$ & $0.10 \pm 0.03$ & $85.03 \pm 4.98$ & $0.58^{*} \pm 0.13$ & $0.18 \pm 0.04$ & $66.91^{*} \pm 12.80$ \\
\hline $20+\mathrm{SA}$ & $0.86 * \pm 0.11$ & $0.14 \pm 0.01$ & $83.54 * \pm 2.10$ & $0.55^{*} \pm 0.15$ & $0.11 \pm 0.03$ & $78.41 \pm 1.95$ & $0.47 * \pm 0.10$ & $0.22 \pm 0.06$ & $52.68^{*} \pm 4.77$ \\
\hline $25+$ SA & $0.77 * \pm 0.12$ & $0.14 \pm 0.02$ & $81.28^{*} \pm 1.37$ & $0.51 * \pm 0.05$ & $0.12 \pm 0.01$ & $76.11 \pm 0.51$ & $0.44 * \pm 0.10$ & $0.21 \pm 0.05$ & $51.70 * \pm 1.78$ \\
\hline
\end{tabular}

Table 4. Growth parameters of peanut plants were hydroponically cultured for 3 days in Hoagland solution $(1 / 2$ strength) supplemented with different concentration of PEG in the absence or presence of $0.1 \mathrm{mM} \mathrm{SA}$ at $26 \pm 2{ }^{\circ} \mathrm{C}$ and $16 / 8 \mathrm{~h}$ photoperiod. Values are mean $\pm \mathrm{SD}$. * Sign to significant difference between the control and other treatments at $\mathrm{P} \leq 0.5$.

Esterase isoenzyme forms under the influence of $\mathrm{NaCl}$ concentrations is shown in Figure (1A).Staining intensity of esterase bands increased in roots when seedlings were subjected for moderate $\mathrm{NaCl}$ concentration (lane R2). Under these conditions new isoenzyme form was detected (lane R2; EST11) but it was not detected in seedling shoot. Under relatively high $\mathrm{NaCl}$ concentration, staining intensity and isoenzyme number decreased roots but increased in shoots of seedlings.The staining intensities of most bands in roots were lower than those of shoots. Two esterase isoenzyme forms (EST-1 and EST-2) were detected in seedling shoots and their staining intensity increased when SA was used (Fig. 1B). In addition, SA induced the expression of new band (EST-10) in seedling roots or shoots. The increase or decrease in isoenzyme density refers to an increase or a decrease in enzyme activity (Khavkin and Zabrodina 1994; Hassanein, 1999).
Esterase isoenzyme expression in hydroponic grown peanut plants under salinity stress was visualized in Figure (2). The staining intensity of esterase isoenzyme forms increased with the increase of salt stress in all plant organs (Fig.2B). In addition, EST-1 and EST-2 were only detected in roots and leaves under the influence of salt stress. It was clear that the response of esterase expression in the different tissues of a plant differed depending on the physiological stage (Hassanein, 1999). Chartzoulakis and Klapaki (2000) stated that, the response of plants to salinity stress differs not only from species to species, but also within a particular species. In comparison to plants grown on $\mathrm{NaCl}$ solutions without $\mathrm{SA}$ (Fig 2A), application of SA increased the expression of esterase isoenzymes in all plant organs, where the number and staining intensity of isoenzyme forms increased when peanut plants were hydroponically grown in saline solution containing SA (Fig. 2B). 

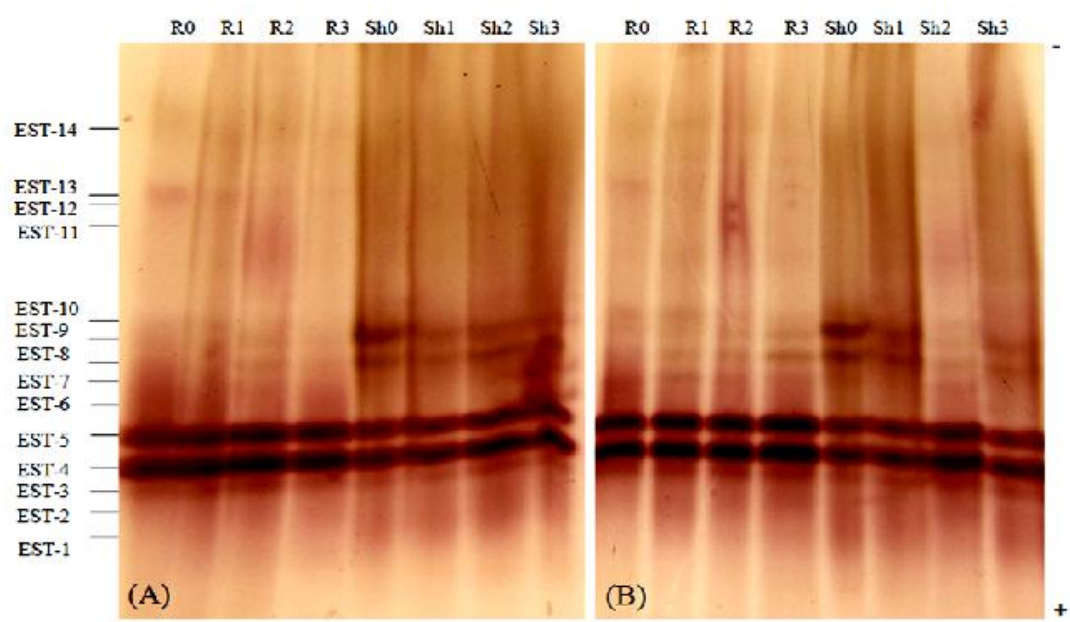

Fig. 1. Native gel electrophoresis for esterase isoenzyme patterns of roots (R) and shoots (Sh) of peanut seedlings grown under the influence of different $\mathrm{NaCl}$ concentrations: $0,45,105$ or $157.5 \mathrm{mM}$ (referred to as $0,1,2$ or 3 , respectively) without (Fig. A) or with (Fig. B) $0.1 \mathrm{mM} \mathrm{SA.}$
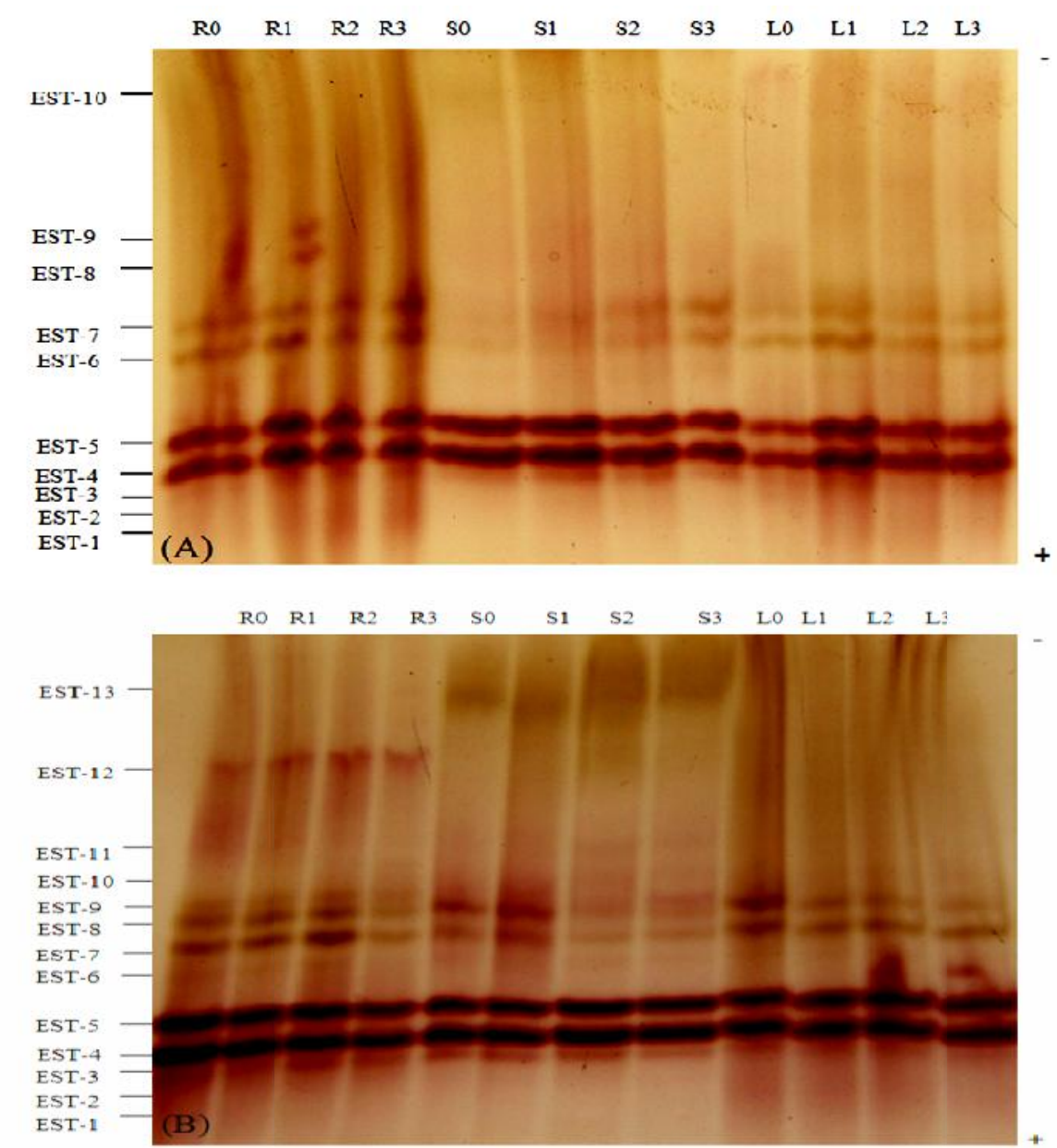

Fig. 2. Esterase isoenzymes profiles of roots (R), stems (S) and leaves (L) of peanut plants grown hydroponically under the influence of different $\mathrm{NaCl}$ concentrations: $0,45,105$ or $157.5 \mathrm{mM}$ (referred to as $0,1,2$ or 3, respectively) without (Fig. A) or with (Fig. B) 0.1 mM SA. 
Drought stress, due to the application of PEG, enhanced esterase expression in roots of peanut seedlings more than the shoots, either in absence or presence of SA (Fig. 3), where some bands were detected in roots (EST-1 and EST-2) but disappeared in shoots. In addition, roots growth parameters were better than those of shoots. Peanut root increased the expression of esterases through: 1) increase the number of esterase isoenzyme forms where EST-1, EST2 and EST-11 were detected especially under moderate salt stress. 2) the staining intensity of these bands increased under the influence of drought stress. Staining intensities of root bands increased under PEG effect compared to those of control plants, and vice versa in shoots (Fig. 3A). Radic and Pevalek-Kozlina (2010) found that salt-induced some isoesterases as well as mannitol did in roots of Centaurea ragusina. When $10 \%$ PEG was used in combination with SA, growth of root, stem and root were improved, the condition which increased the density of some esterase bands (Lanes R2 and Sh2 in Fig 3B). Generally, the staining intensity of esterse bands of shoots increased under the effect of PEG in combination with SA.

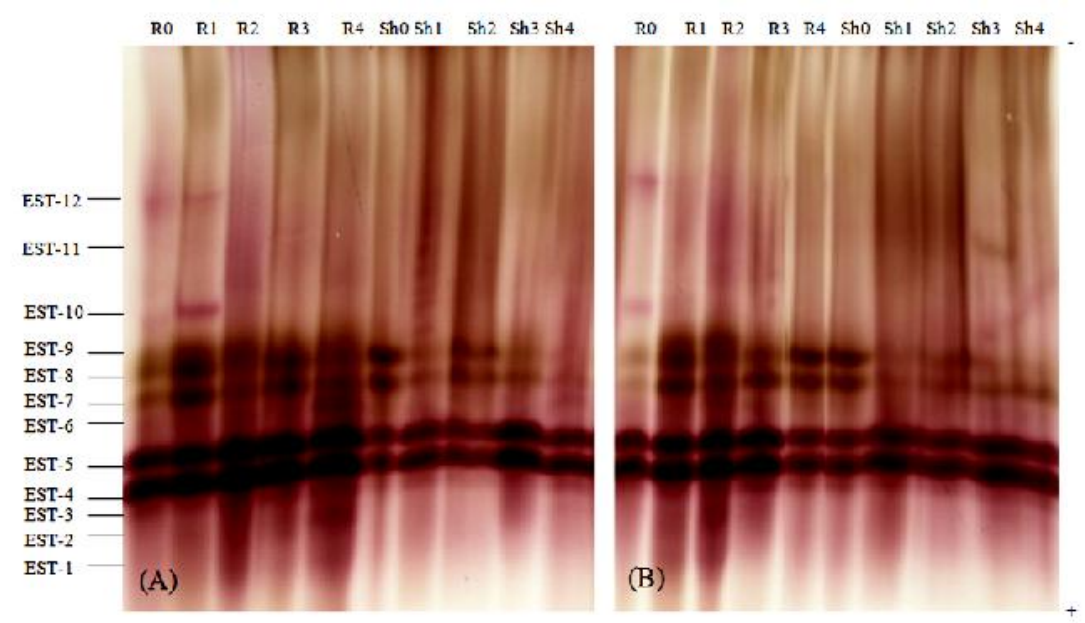

Fig. 3. Esterase isoenzymes patterns of roots $(\mathrm{R})$ and shoots (Sh) of peanut seedlings grown under the influence of PEG different concentrations: $0,5,10,15$ or $20 \%$ (referred to as: 0, 1, 2, 3 or 4, respectively) without (Fig. A) or with (Fig. B) $0.1 \mathrm{mM} \mathrm{SA}$.

The differential response of different plant organs to PEG stress was observed in esterase patterns of peanut plants that were hydroponically grown in absence or presence of SA (Fig. 4). In SA free hydroponic culture, eight esterase isoenzymes were expressed in roots versus six in stems and five in leaves of untreated control plants. Also, the staining intensity of esterase bands increased under the influence of PEG compared to the control of each organ, similar to salinity. Salicylic acid stimulated the expression of extra esterase isoenzymes in peanut plants cultured hydroponically under the influence of PEG. In general, 10-12 isoesterases in roots and 7-8 isofroms in stems of peanut plants were characterized in presence of SA (Fig. 4B). The appearance of these new isoforms under the presence of SA may be attributed to the potentiality of SA to trigger specific gene expression under drought stress. The increase in esterase activity under stress conditions was considered as a defense mechanism against oxidative damage in plants (Lambert et al., 1999; Andres et al., 2001). 

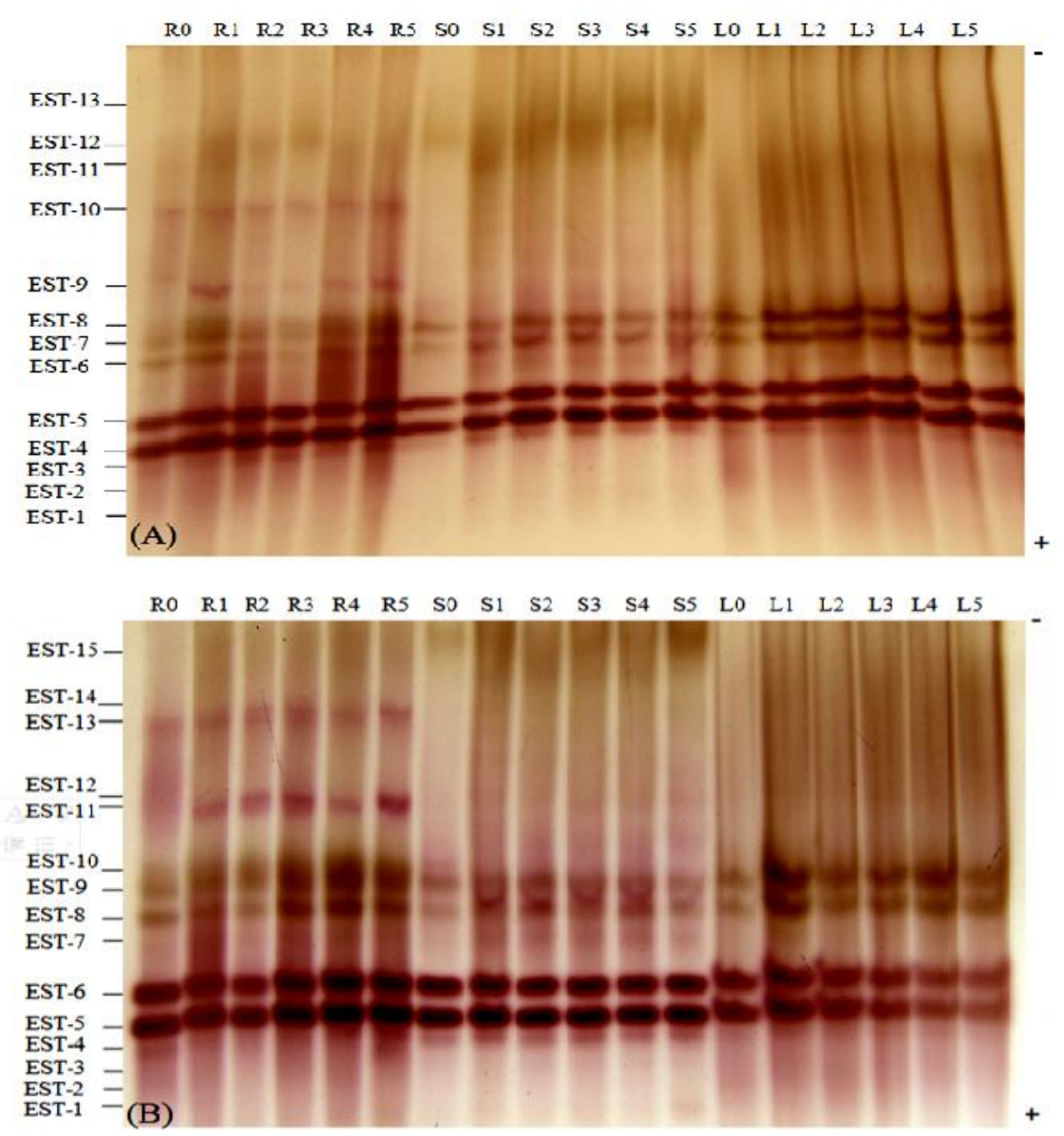

Fig. 4. Native gel electrophoresis foresterase isoenzymes profiles of roots (R), stems (S) and leaves (L) of peanut plantsgrown hydroponically under the influence of $0,5,10,15,20$ or $25 \%$ (referred to as $0,1,2,3,4$, or 5 , respectively) PEG, without (Fig. A) or with (Fig. B) 0.1 mM SA.

Under studied conditions, the majority of isoesterase bands were purple red and only few ones were dark brown after gel staining with $\alpha$ - and $\beta$-naphthyl acetate. This indicated the preference of peanut organs isoesterases toward $\beta$-naphthyl acetate, while preference of some others toward $\alpha$-naphthyl acetate where bands were brown. Radic and Pevalek-Kozlina (2010) observed that the majority of isoesterase bands of Centaurea ragusina leaves were dark brown and few were purple red after gel staining with $\alpha$ - and $\beta$-naphthyl acetate, while isoesterase bands of roots did not exhibit any preference toward a certain substrate.

\section{References:}

Abdel-Rahman, A.M. and Hassanein, A.M. (1988). Interactive effect of soil water content and antitranspirant (PMA) on some physiological activities in maize plant. Acta Agronomica Hungarica. 37: 19-29.

Andres, M.F., Romero, M.D., Montes, M.J. and Delibes, A. (2001). Genetic relation-ships and isozyme variability in Heterodera avenae complex determined by isoelectro focusing. Plant Pathology 50: 270-279.

Arfan, M., Athar, H.R. and Ashraf, M. (2007). Does exogenous application of salicylic acid through the rooting medium modulate growth and photosynthetic capacity in two differently adapted spring wheat cultivars under salt stress. Journal of Plant Physiology. 6(4): 685-694.

Ashraf, M.Y. (2009). Biotechnological approach of improving plant salt 
tolerance using antioxidants as markers. Biotechnology Advances. 27: 84-93.

Baalbaki, R.Z., Zurayk, R.A., Blelk, R.A. and Tahouk, S.N. (1999). Germination and seedling development of drought tolerance and susceptible wheat under moisture stress. Seed Science and Technology. 27: 291-302.

Baninasab, B. and Baghbanha, M.R. (2013). Influence of salicylic acid pretreatment on emergence and early seedling growth of cucumber (Cucumis sativus) under salt stress. International Journal of Plant Production. 7(2): 187-206.

Brewer, G.J. (1970). An Introduction to Isoenzymes Techniques. Academic Press.

Chartzoulakis, K. and Klapaki, G. (2000). Response of two greenhouse pepper hybrids to $\mathrm{NaCl}$ salinity during different growth stages, Scientia Horticulturae. 8: 247.

Chawla, H.S. (1991). Regeneration potentiality and isoenzyme variation during morphogenesis of barely callus. Biologia Plantarum. 33: 175-180.

Devlin, M.R. and Witham, H.F. (1980). (ed.): Plant physiology. CBS Publishers and Distributors, Delhi.

El-Tayeb, M.A. (2005). Response of barley grains to the interactive effect of salinity and salicylic acid. Plant Growth Regulators. 45:215-224.

El-Tayeb, M.A. and Hassanein A.M. (2000). Germination, seedling growth, some organic solutes and peroxidase expression of different Vicia faba lines as influenced by water stress. Acta Agronomica Hungarica. 48: 11-20.

Gunes, A., Inal, A., Alpaslan, M., Cicek, N., Guneri, E., Eraslan, F. and Guzelordu, T. (2005). Effects of exogenously applied salicylic acid on the induction of multiple stress tolerance and mineral nutrition in maize (Zea mays L.). Archives of Agronomy and Soil Science. 51: 687-695.

Gunes, A., Inal, A., Alpaslan, M., Eraslan, F., Bagci, E.G. and Cicek, N. (2007).
Salicylic acid induced changes on some physiological parameters symptomatic for oxidative stress and mineral nutrition in maize (Zea mays L.) grown under salinity. Journal of Plant Physiology. 164: 728-736.

Hassanein, A.M. (1997). Isoenzyme patterns of Solanum nigrum and the cybrid plant cotaining $S$. nigrum genome and S. tuberosum plastome. Biologia Plantarum. 40: 617-621.

Hassanein, A.M. (1999). Alterations in protein and esterase patterns of peanut in response to salinity stress. Biologia Plantarum. 42(2): 241-248.

Hassanein, A.M. (2004). Effect of relatively high concentration of mannitol and sodium chloride on regeneration and gene expression of stress tolerant (Alhagi graecorum) and stress sensitive (Lycopersicon esculentum L) plant species. Bulgarian Journal of Plant Physiology. 30: 19-36.

Hassanein, A.M., Ahmed, A.M., Abdel-Hafez, A.I.I. and Soltan, D.M. (1999): Isoenzymes expression during root and shoot organogenesis of Solanum nigrum. Biolgia Plantarum 42: 341347.

Hoagland, D.R. and Arnon, D.I. (1950). The water-culture method of growing plants without soil. California Agricultural Experiment Station. Circular, 347.

Jadhav S. H. and Bhamburdekar S. B. (2011). Effect of saicylic acid on germination performance in groundnut. International journal of Applied Biology and Pharmaceutical Technology. 2(4): 224-227.

Jamil, M. and Rha, E.S. (2004). The effect of salinity $(\mathrm{NaCl})$ on the germination and seedling of sugar beet (Beta vulgaris L.) and cabbage (Brassica oleracea capitata L.). Korian Journal of Plant Research. 7:226-232.

Kabiri, R., Farahbakhsh, H. and Nasibi, F. (2012). Effect of drought stress and its interaction with salicylic acid on black cumin (Nigella sativa) germination 
and seedling growth. World Applied Sciences Journal. 18(4): 520-527.

Kalefetoglu Macar, T., Turan, O. Ekmekci, Y. (2009). Effect of water deficit induced by PEG and $\mathrm{NaCl}$ on chickpea (Cicer arietinum L.) cultivar and lines at early seedling stage. Gazi University Journal of Science. 22:5-14.

Karagić, Đ., Katić, S., Mikić, A., Vujaković, M., Milić, D., Vasiljević, S., Milošević, B. (2010). Effects of genotype and mechanical damage during harvest on field pea (Pisum sativum L.) seed quality. Genetika. 42(3):425-434.

Khavkin, E.E. and Zabrodina, M.V. (1994). Heritable variation in peroxidase and esterase isoenzyme patterns of maize somaclone. Fiziol, Rast. 41: 754-761.

Lambert, K.N., Ferrie, B.J., Nombela, G., Brenner, E.D. and Williamson, V.M. (1999). Identification of genes whose transcripts accumulate rapidly in tomato after root-knot nematode infection. Physiological and Molecular Plant Pathology. 55: 341-348.

Liu, H., Wang, X., Wang, D., Zou, Z. and Liang, Z. (2011). Effect of drought stress on growth and accumulation of active constituents in Salvia miltiorrhiza Bunge. Industrial Crops and Products. 33:84-88.

Mahajan, S., Tuteja, N. (2005). Cold, salinity and drought stresses: An overview. Archives of Biochemistry and Biophysics. 444: 139-158.

McCue, P., Zheng, Z., Pinkham, J.L. and Shetty, K. (2000). A model for enhanced pea seedling vigor following low $\mathrm{pH}$ and salicylic acid treatments. Process of Biochemistry. 35: 603-613.

Meneguzzo, S., Navarri-Izzo, F. and Izzo, R., (1999). Antioxidative responses of shoot and root of wheat to increasing $\mathrm{NaCl}$ concentrations. Journal of Plant Physiology. 155: 274-280.

Misra, N. and Dwivedi, U.N. (2004). Genotypic differences in salinity tolerance of green gram cultivars. Plant Science. 166: 1135.
Nemeth, M., Janda, T., Horvath, E., Paldi, E. and Szalai, G. (2002). Exogenous salicylic acid increases polyamine content but may decrease drought tolerance in maize. Plant Science. 162: 569-574.

Petrovic, G., Jovicic, D., Nokolic, Z, Tamindzic, G., Ignjatov, $\mathrm{M}$, Milosevic, D. and Milosevic, B. (2016). Comparative study of drought and salt stress effects on germination and seedling growth of pea. Genetika, 48(1): 373-381.

Qadir, M., Quille'rou, E., Nangia, V., Murtaza, G., Singh, M., Thomas, R.J., Drechsel, P. and Noble, A.D. (2014). Economics of salt-induced land degradation and restoration. Natural Resources Forum. 38: 282-295.

Radic, S. and Pevalek-Kozlina, B. (2010). Differential esterase activity in leaves and roots of Centaurea ragusina $\mathrm{L}$. as a consequence of salinity. Periodicum Biologorum. 112(3): 253-258.

Scandalios, J.G. (1974). Isoenzymes in development and differentiation. Annual Review of Plant Physiology. 25: 225-258.

Shakirova, F.M., Sakhabutdinova, R.A., Bezrukova, M.V., Fatkhutdinova, R.A. and Fatkhutdinova, D.R. (2003). Changes in the hormonal status of wheat seedlings induced by salicylic acid and salinity. Plant Science. 164: 317-322.

Singh, B. and Usha, K. (2003). Salicylic acid induced physiological and biochemical changes in wheat seedlings under water stress. Plant Growth Regulators. 39: 137-141.

Snedecor, G.W. and Cochran, W.G. (1980). Statistical methods. Oxford and J. B. H. Publishing Com. $7^{\text {th }}$. In: I. A. Ames (ed.). Iowa State Univ, 166-190.

Steduto, P., Albrizio, R., Giorio, P. and Sorrentino, G. (2000). Gas exchange response and stomatal and nonstomatal limitations to carbon assimilation of sunflower under salinity. Environmental and Experimental Botany. 44: 243-255. 
Szepesi, A., Csiszar, J., Gémes, K., Horvath, E., Horvath, F., Simon, M.L., Tari, I. (2009). Salicylic acid improves acclimation to salt stress by stimulating abscisic aldehyde oxidase activity and abscisic acid accumulation, and increases $\mathrm{Na}+$ content in leaves without toxicity symptoms in Solanum lycopersicum L. Journal of Plant Physiology. 166: 914-925.

Takel, A. (2000). Seedling emergence and growth of sorghum genotypes under variable soil moisture deficit. Acta Agronomica Hungarica. 48: 95-102.

Tamás L., Huttová, J., Mistrík, I., Šimonovičová, M. and Široká, B. (2005). Aluminium induced esterase activity and isozyme patternin barley root tip. Plant Soil Environment. 51 (5): 220-225.

Van-De-Vanter, A. (2001). Seed Vigor testing. ISTA. New Bull. 122: 12-14.
Verslues, P.E., Agarwal, M., Katiyar-Agarwal, S., Zhu, J. and Zhu, J.K. (2006). Methods and concepts in quantifying resistance to drought, salt and freezing, abiotic stresses that affect plant water status. Plant Journal. 45: 523-539.

Xu, Q., Xu, X., Zhao, Y., Jiao, K., Herbert, J.S. and Hao, L. (2008). Salicylic acid, hydrogen peroxide and calciuminduced salinity tolerance associated with endogenous hydrogen peroxide homeostasis in naked oat seedlings. Plant Growth Regulators. 54: 249259.

Younis, M.E., Hassanein, M.N.A. and NemetAlla, M.M. (1987). Plant growth, metabolism and adaptation in relation to stress conditions. IV. Effects of salinity on certain factors associated with the germination of three different seeds high in fats. Annals of Botany. 60: $337-344$.

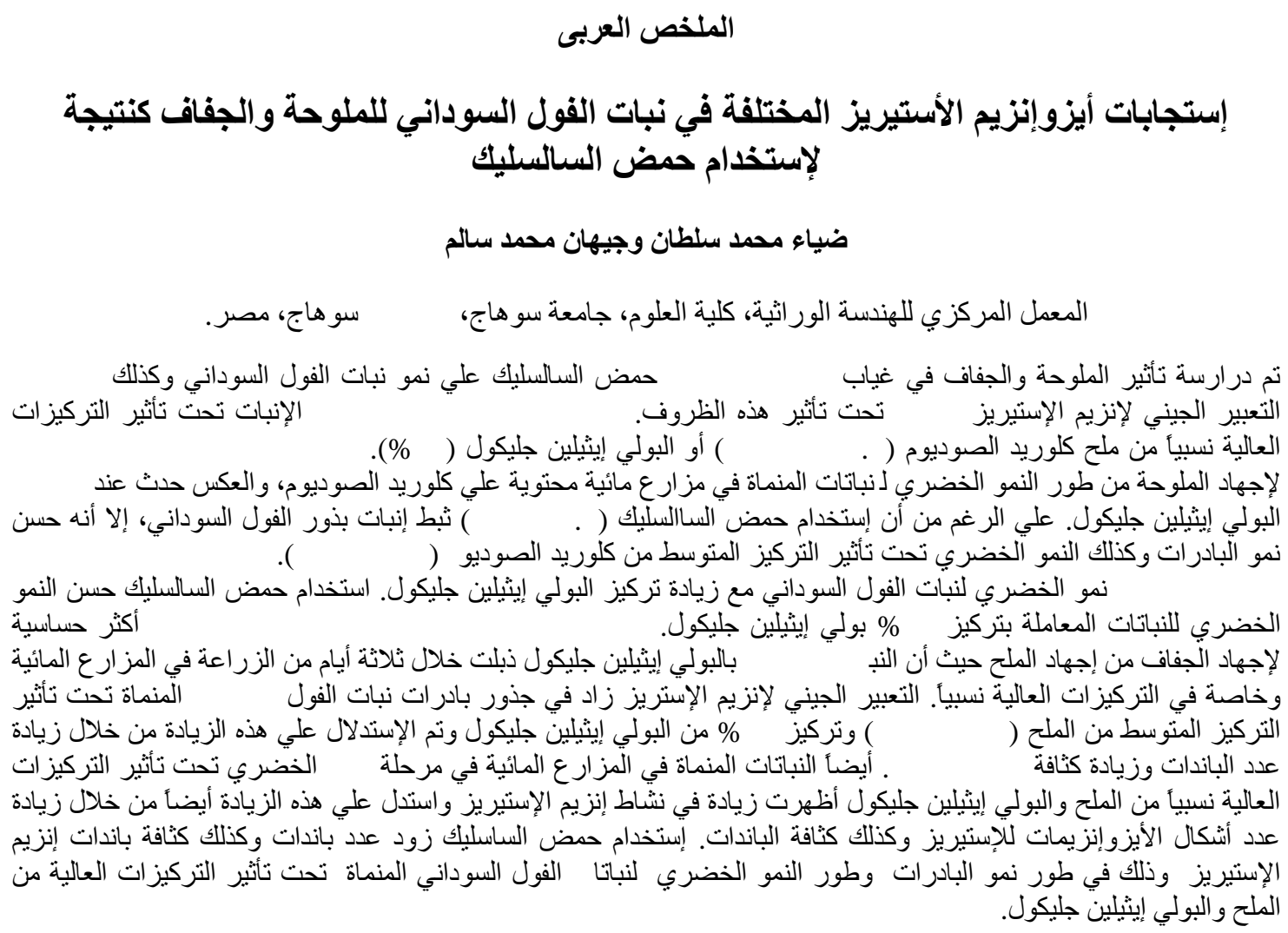

